\title{
On Relative Clauses and Prosodic Phrasing in Ciwandya
}

\author{
Al Mtenje \\ University of Malawi
}

The interaction between Syntax and Phonology has been one area of interesting empirical research and theoretical debate in recent years, particularly the question of the extent to which syntactic structure influences phonological phrasing. It has generally been observed that the edges of the major syntactic constituents (XPs) tend to coincide with prosodic phrase boundaries thus resulting in XPs like subject NPs, object NPs, Topic NPs, VPs etc. forming separate phonological phrases. Within Optimality Theoretic (OT) accounts, this fact has been attributed to a number of well-motivated general alignment constraints. Studies on relative clauses in Bantu and other languages have significantly contributed to this area of research inquiry where a number of parametric variations have been observed with regard to prosodic phrasing. In some languages, XPs which are heads of relatives form separate phonological phrases while in others they phrase with the relative clauses. This paper makes a contribution to this topic by discussing the phrasing of relatives in Ciwandya (a Bantu language spoken in Malawi and Tanzania). It shows that XPs which are heads of restrictive relative clauses phrase with their relative verbs, regardless of whether they are subjects, objects or other adjuncts. A variety of syntactic constructions are used to illustrate this fact. The discussion also confirms what has been generally observed in other Bantu languages concerning restrictive relatives with clefts and non-restrictive relative clauses. In both cases, the heads of the relatives phrase separately. The paper adopts an OT analysis which has been well articulated and defended in Cheng \& Downing (2007, 2010, to appear) Downing \& Mtenje $(2010,2011)$ to account for these phenomena in Ciwandya.

\section{Introduction}

The study of relative clauses has attracted considerable attention in recent years and a number of theoretical models have been proposed to account for this 


\section{Al Mtenje}

phenomenon in several languages (cf. Cheng \& Downing 2007, Downing \& Mtenje 2010, 2011, Henderson 2006, Cheng \& Kula 2006, Kanerva 1990, Morimoto 2007, Morimoto \& Downing 2007, Selkirk 2000, Simango 2006, Truckenbrodt 1995, 1999, Zeller 2004 and others). This paper presents a description of the prosodic structure of relative clauses in relation to various syntactic structures in Ciwandya, a Bantu language spoken in Malawi and Tanzania. It is argued that the prosodic phrasing of restrictive relative clauses in this language, like in several other Bantu languages, is determined by syntactic structure. Particularly, it is shown that like in several other languages, restrictive relative clauses are right-bounded by a prosodic phrase break and that XPs which serve as heads of relative clauses, whether as subjects, objects (both direct and indirect), locatives, temporal or other adjuncts are normally phrased together with the relative clause. One major exception to this general pattern is when such XPs occur in non-restrictive relative clauses and in cleft constructions where they are invariably phrased separately from the relative verb. We follow the analyses of the prosodic phrasing of relatives and clefts as proposed by Cheng \& Downing (2007, to appear) and Downing \& Mtenje $(2010,2011)$ for Chichewa in accounting for these phenomena. ${ }^{1}$

\section{Prosodic and segmental cues of relative clauses}

Relative clauses may be distinguished from main clauses by both segmental and prosodic cues. In a number of Bantu languages, for example in Chichewa (spoken in Malawi and other neighbouring countries) and Cinsenga (spoken in Malawi and Zambia), a prosodic feature like tone can distinguish relative clauses from nonrelatives. In Chichewa, a relative marker may be omitted and the only distinguishing cue for relativization would be a high tone on the subject prefix of a relative verb as seen in the examples in (1) below (an acute accent shows a high tone, the symbol " "” on a vowel marks a falling tone and low tones are unmarked). ${ }^{2}$

1 I would like to thank my Ciwandya informant, Mr. Simbowe for his time and patience during the recording of the data used in this paper. My other gratitude goes to many colleagues who attended the B4ntu Conference in Berlin, 7th-10th April 2011, for their comments on some aspects of the paper. Needless to say that none of them are responsible for any errors in the analysis, interpretation or presentation adopted in this paper.

2 The following abbreviations have been used in this paper: Adv = Adverb; Appl = Applicative; $\mathrm{Cl}=$ Class; $\mathrm{Cop}=$ Copula; Fut = Future; Hab = Habitual; Inf = Infinitive; Loc $=$ 
(1) Non-relative clause (subject prefix /i/ has a low tone)
a. M-balá i-ná-bá n-dalámá z-aángá cl9-thief 9subj-past-steal cl10-money cl10-my
'The thief stole my money.'

Relative clause (subject prefix /i/ has a high tone)

b. M-balá í-ná-bá n-dalámá z-aángá

'The thief who stole my money'

Cinsenga, like Chichewa, also has the option of prosodically marking relativization through tone. In (3), the high tone on the subject prefix /a/ signals a relative clause while its low tone counterpart in (2) shows a non-relative structure.

(2) Non- relative (transitive)

a-kú-lyá mûmbu

s/he-hab-eats maize

'She eats maize'

(3) Relative (transitive)

á-kú-lya mûmbu

'S/he who eats maize'

(Miti 2002)

Languages may also use segmental cues to mark relative clauses. In Chichewa, for example, relative clauses are also shown by the morphemes -mene and -o (with appropriate prefixes placed in front of them to signal agreement with the head of the relative verb). While these relative morphemes are optional, as seen in (1) above, when they are used, they are restricted to specific syntactic positions as shown below.

(4) -mene in front of relative clauses ( $\}$ = relative clause boundary)
m-balá
i-méné í-ná-bá
n-dalámá z-àángá\}
cl9-thief
cl9-rel 9subj-past-steal
cl10-money cl10-my
i-ku-tháawa.

Locative; Neg = Negative; Obj = Object; Perf = Perfective; Plur = Plural; Prog = Progressive; Rc = Relative clause; Rel = Relative; Subj = Subject. 


\section{Al Mtenje}

9subj-prog-run away

'The thief who stole my money is running away.'

(5) -yo at the end of a relative clause

m-balá í-ná-bá n-dalámá zangáa-yo\}

(6) with both -mene and -yo

m-balá i-méné í-ná-bá n-dalámá zangáa-yo\}

(cf. Downing \& Mtenje 2010, 2011 for these and other relevant data)

It is typical of relative morphemes to be positionally restricted. For example, mene or -yo cannot occur in the positions shown below.

(7) a. *m-balá í-ná-bá i-méné n-dalámá zàángá\}

b. *m-balá í-ná-bá n-dalámá-yo zàángá\}

c. *m-balá yo í-ná-bá n-dalámá zàángá\}

d. *m-balá í-ná-bá n-dalámá zàángá i-méné\}

\section{A brief overview of Ciwandya}

Ciwandya is a Bantu language spoken in Chitipa district in northern Malawi and the following areas of Tanzania: Mbeya, Rukwa, Mbozi and Simbawanga. It has been classified by Ethnologue as belonging to the Nyika-Safwa group in M20 and it is alternatively known as Wandia, Iciwanda, Vanda and Kiwanda. It is closely related to Icinamwanga and the lexical similarity between the two languages is estimated at $68 \%$. The exact number of Ciwandya speakers in Malawi is not known but it is generally regarded as one of the "small" languages in the country. The data used in this paper is from the Malawi variety of Ciwandya.

\section{The morphology of Ciwandya relative clauses}

Relative clauses in Ciwandya are marked by the morpheme -o which usually occurs in front of the relative verb and has a consonant in front of it whose shape is determined by the noun class of the XP which serves as the head of the relative clause. This is exemplified in (8) below.

$\begin{array}{ll}\text { u-mwívi yó } & \text { a-ki-wa } \\ \text { cl1-thief cl1.rel } & \text { cl1- past-steal }\end{array}$

i-ndaláma zy-aane \} a-ku-samáala cl9 money cl9-my cl1-prog-run away 
'The thief who stole my money is running away'

This relative morpheme in Ciwandya is obligatory as shown in (9) where its omission results in an ungrammatical structure.

(9) *u-mwívi a-ki-wa i-ndaláma zy-aane\} a-ku-samáala

It is possible in Ciwandya to have more than one relative marker as shown in (10) where there is a second occurrence of the morpheme. ${ }^{3}$

u-mwívi yó a-ki-wa i-ndaláma zy-ane úuyo a a-ku- samáala

Like in other languages, there are restrictions with regard to the distribution of -yo. This morpheme cannot be at the end of a relative clause, except when it is repeated, as in (10) above, in which case it must be prefixed by a vowel, neither can it appear in any other position. This is illustrated below.

(11) a. *u-mwívi a-ki-wa i-ndaláma zy-aane-yó\} a-ku-samáala

b. *u-mwívi a-ki-wa i-ndaláma yó zy-aane\} a-ku-samáala

c. *u-mwívi a-ki-wa yó i-ndaláma zy-aane\} a-ku-samáala

d. *u-mwívi a-ki-wa i-ndaláma zy-aane\} a-ku-samálaa yô

\subsection{Relative clauses and phonological phrasing}

One of the major phonological characteristics of relative clauses, in most languages, is the fact that they are marked by a phonological phrase boundary on their right edge when they occur in different types of syntactic constructions. In a number of Bantu languages, such phrase edges are usually shown by prosodic features such as vowel length and contour tones on certain syllables. For instance, in Zulu, penultimate vowel length marks the right edge of a phonological phrase (cf. Cheng \& Downing 2010) just as vowel length and contour tones on penultimate syllables indicate the right end of a phonological phrase in Chichewa (cf. Downing \& Mtenje 2010, 2011). Likewise, in Chimwiini vowel length and pitch features like accent/stress or high tones on penultimate and final syllables serve as cues for phrasal edges (cf. Kisseberth 2010 for details). Cheng \& Kula

3 Here, the relative clause makes reference to a specific thief and, according to the informant, it is preferred that the second relative morpheme should have a prefix in front of it. 
(2006) also argue that the location of high tones shows phrasal boundaries in Bemba.

In Ciwandya, the right edges of relative clauses are prosodically marked by long vowels on penultimate syllables and, wherever applicable, contour tones on those syllables. In this paper, we use data elicited through a structured questionnaire which involved relative clauses in the following syntactic constructions: clefts, headless relatives, coordinated and extraposed relative clauses, relatives whose heads are direct objects, indirect objects, locatives, temporal adjuncts and instrumentals.

We begin by looking at restrictive relative clauses (RCs) whose heads are subjects of the relative verb and show their prosodic phrasing (a square bracket shows the edge of a phonological phrase).

\subsection{Subject relatives}

In the constructions in (12) and (13) below, we see that the head of the RC (which is its subject) is phrased together with the relative verb and that there is a prosodic boundary at the right edge of the RC. The conclusion that the subject head of the relative clause phrases with the rest of the RC stems from the fact that this NP does not have a long penultimate syllable which, as stated above, marks phrasal boundaries in Ciwandya and many other Bantu languages. Using the same criterion of vowel length for detecting phrasal edges, we note that the right edges of the relative clauses have long penultimate syllables in the forms [zyaane] and [nkháani] in (12) and (13) respectively. This, therefore, shows that there is a phonological phrase break at the right of the relative clauses.

Head of relative clause is subject of relative verb

u-mwívi yó a-ki-wa i-ndálámá

i-ndálámá zy-aane\}] a-ku-samáala cl1-thief 1.rel cl1-past-steal cl9-money cl9-my cl1-prog-run away 'The thief who stole my money is running away'

u-m’mányisi yó a-ka-kalalá nkháani\}] a-ka-wa-welengera cl1-teacher 1.rel cl1-past-be angry very much cl1-past-obj-read to a-wana a-sukúlu u-kaláata cl2-children cl2-school cl5-letter 'The teacher who was very angry read the students a letter' 
This phonological phrasing pattern holds even in cases where the head of the RC is an instrumental as observed in (13') below where the head, the instrumental NP [i-cipéni], phrases with the rest of the relative clause as seen in the fact that this NP does not have a long penultimate syllable, a characteristic of phrase-final elements in Ciwandya.
(13’)
i-cipéni có tu-ka-cek-ela
u-buléedi\}] ca-búumpha
cl7-knife 7.rel we-past-cut-with cl3-bread cl7-perf-be blunt
'The knife with which we cut the bread has become blunt'

The prosodic pattern observed in (12) and (13) above also shows up in other Bantu languages. For instance, in Chichewa (cf. Downing \& Mtenje 2010, 2011) and in Durban Zulu (cf. Cheng \& Downing 2010) subjects of relative verbs phrase together with the RC. In Chimwiini, the situation is partially similar. According to Kisseberth (2010), the head of the RC in subject relatives may be phrased with the $\mathrm{RC}$ verb when it precedes it, but not always, while in Símákonde the situation is different since the subject NP of a relative clause never phrases together with the relative verb (cf. Manus 2010 for details).

While subjects of relative verbs in Ciwanndya phrase with the RC in restrictive relative clauses, non-restrictive relatives behave differently in that their heads always phrase separately from the RC. This is shown in the non-restrictive version of the sentence in (13) above which is repeated below as (14).
u-m’mányiisi] yó a-ka-kalalá nkháani\}] a-ka-wa-welengela a-wána a-sukúlu u-kaláata

As it can be seen here, there is a prosodic phrase boundary after the head of the RC (um'mányiisi) and, as expected, at the right edge of the relative clause. This prosodic phrasing is generally found in many other Bantu languages including Chichewa (cf. Downing \& Mtenje 2010, 2011) and Zulu (cf. Cheng \& Downing 2010).

\subsection{Object relatives}

Object relatives behave like subject relatives with regard to phonological phrasing. When the head of the relative clause is an object (direct or indirect), it phrases with 
the relative verb regardless of whether it is topicalized or not. This is shown in (15) - (20) below.

\subsubsection{Direct object relatives}

(15) Head of RC is direct object of main clause u-mwána wa-sukúlu a-ka-simba u-kaláta yó u-m’mányisi cl1-child of cl9-school cl1-past-write cl5-letter 5.rel cl1-teacher a-ka-weleng-ela ku wa nyúuzi\}] cl1-past-read to of newspaper 'The student wrote the letter which the teacher read for the newspaper'

(16) Head of $R C$ is direct object of relative clause n-kha-wa-úzya yó u-Mary a-mu-ghán-iite\}] I-past-2obj-tell 1.rel cl1-Mary 1-1obj like-hab 'I told them who Mary likes'

(17) Head of RC is topicalized direct object of RC u-kaláta yó u-m’mányisi a-ka-weléenga\}] yi-ka-mu-nena cl5-letter 5.rel cl1-teacher cl1-past-read cl9-past-obj1-say i-mfúumu cl9-chief 'The letter the teacher read criticizes the chief' a-wa-léndo wó u-Bánda a-ka-wa-línga m’-mawiíla\}] wa-úuka cl2-visitors 2.rel cl1-Banda cl1-past-obj-see yesterday cl2-perf-go 'The visitors who Banda saw yesterday have gone'

\subsubsection{Indirect object relatives}

Following the same phrasing pattern observed above, the indirect object NPs phrase with their relative verbs in (19) and (20) below. 
Head of relative clause is indirect object of $R C$

$\begin{array}{llll}\text { u-mú-luméndo yó } & \text { u-mú-nyaáwo u-ka-n-dangizya } & \text { úune\}] } \\ \text { cl1-boy } & \text { 1-rel } & \text { 1-his friend } & \text { you.sg-past-me-show him } \\ \text { a-li pa-nóonye } & & & \\ \text { cl1-is here } & \end{array}$

'The boy whose friend you introduced me to is here'

(20)

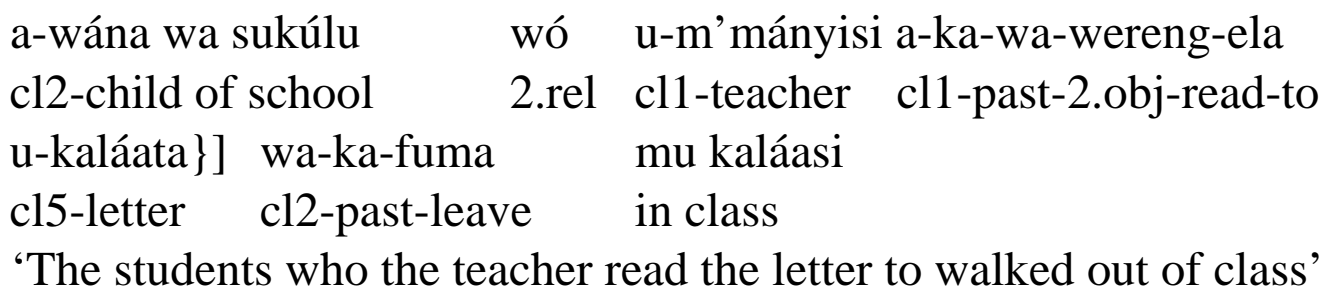

It is interesting to note that in other Bantu languages, the situation is different. In Chimwiini, for example, unlike subject relatives, non-subject relative heads which precede relative verbs are never phrased together with RCs (cf. Kisseberth 2010).

\subsection{Headless relatives}

There are different situations in which RCs may be headless. Here we will look at two cases. We will begin by examining simple relative clauses which have no overt XPs as heads and then look at stacked headless relatives. It will be observed that in both cases, the only prosodic break is the one which always marks the right edge of each relative clause. This is illustrated in the examples below.

\subsubsection{Headless subject relatives}

(21) wó wa-ka-mu-linga u-Bánda m’-mawiíla\}] wa-wúuka 2.rel cl2-past-1.obj-see cl1-Banda yesterday cl2-perf-go

'The ones who saw Banda yesterday have gone'

(22) Subject of RC is in embedded clause tu-ta-m-ménye yó a-kw-angala pá mbali pa-lu-sóoko\}] we-neg.prog-1.obj-know 1.rel cl1-prog-play loc-by loc-cl3-river 'We don't know who is playing by the river'

\subsubsection{Headless direct object relative}




\section{Al Mtenje}

(23)

wó u-Bánda a-ka-wa-linga m’mawiíla\}] wa-wúuka 2.rel Banda cl1-past-2.obj-see yesterday cl2-perf-go

'The ones who Banda saw yesterday have gone'

\subsubsection{Headless indirect object relative}

24) wó u-Bánda a-ka-wa-pa i-mpháaso\}] wa-ku-mu-salíifya 2.rel Banda cl1-past-2.obj-give cl9-gift cl2-past-1.obj-thank 'The ones who Banda gave presents to, thank him'

\subsubsection{Stacked headless relatives}

When more than one relative clause occurs in a sentence, the same phrasing pattern noted above is observed, namely, the only phonological phrase break is at the end of each relative clause. This is shown in (25) below.

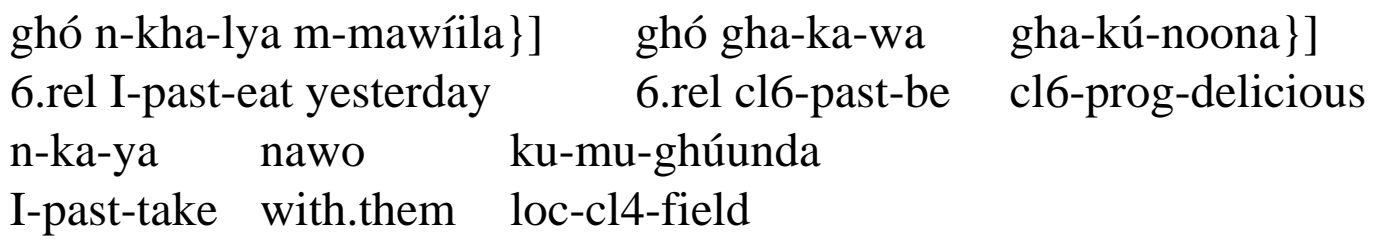

'Those which I ate yesterday, which were delicious, I took them to the field'

There are other Bantu languages which show the same prosodic phrasing for headless relatives as noted above for Ciwandya. In Cisena, for example, both subject and object headless relatives only have a prosodic break at the end of the relative clause (cf. Mtenje 2011). The same is true of Chichewa (cf. Downing \& Mtenje 2010, 2011 for details).

\section{Clefts}

In Ciwandya, as in other Bantu languages, XPs in clefts are never phrased together with their corresponding relative clauses. This is regardless of whether such XPs are subjects or objects of their relative verbs (cf. Kisseberth 2010 for Chimwiini, Cheng \& Downing 2010 for Zulu, Mtenje 2011 for Cisena, Downing \& Mtenje 2011 for Chichewa for similar observations). We illustrate this with the examples below. 


\subsection{Direct object cleft}
wo wa-mányiisi] wó a-ka-wa-linga
m-mawiíla\}]
be cl2-teacher 2.rel cl1-past-2.obj-see yesterday
'It is teachers he saw yesterday'

Note that in the example above, there are two occurrences of the form [wo]. The low toned [wo] stands for the copula 'to be' while the one with the high tone represents the usual relative morpheme. In terms of prosodic phrasing, it can be observed that the object NP [mányiisi], which is clefted, has a long penultimate vowel showing that it is phrase final. Likewise, in the next example in (27), the same word, where it now serves as the subject of the relative clause, occurs with a long penultimate vowel, a clear sign that it is at the edge of a phrase break.

\subsection{Subject cleft}

\begin{tabular}{|c|c|c|}
\hline wa-mányiisi] & wó wa-ka-simba & u-kaláata\}] \\
\hline l2-teacher & 2.rel cl2-past-write & cl5-letter \\
\hline
\end{tabular}

\subsection{Indirect object cleft}

Indirect object clefts behave like the subject and direct object cleft constructions discussed in examples (26) and (27) above. In (28), the indirect object NP [waléendo] is at the edge of a prosodic phrase boundary as noted by its long penultimate vowel and the falling tone on it.

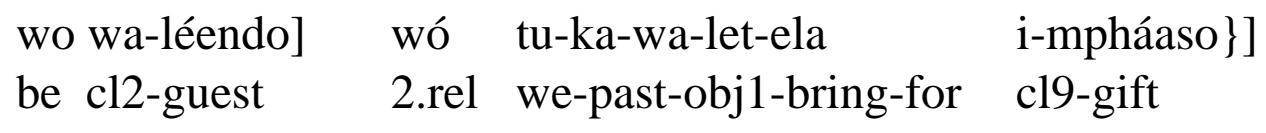

'It's visitors we brought the gifts for'

\section{Locatives, temporal and other adjuncts}

When the head of a relative clause is an XP which stands for a locative, temporal or any other adjunct, it phrases together with the RC, just like in all other non-cleft constructions. This is illustrated in the examples in (29)-(32) below where the only phonological phrase break, shown through the presence of a long penultimate vowel, is at the end of the relative clauses. 


\section{Al Mtenje}

Head of $R C$ is Locative

(29) i-sitólo yó mu-nga-ghulá-ko a-mabúuku\}] yi-li pa-píipi cl9-store 9.rel you.pl-can-buy-loc cl6-book cl9-be loc-near 'The store where you can buy books is near'

(30) a-málo ghó n-ka-kumana náaye\}] gha-li pa-pípi na ku-nóonye cl6-place 6.rel I-past-meet with her 6-is loc-near to here 'The place where I met her is close to here'

Head of $R C$ is temporal expression

$\begin{array}{llll}\text { (31) pí-siku lyó u-mwána wáne } & \text { a-ká-papíiwa\}] } & \text { n-ka-womba } \\ \text { on-cl5.day } & 5 \text {.rel cl1-child cl1-my } & \text { cl1-past-be.born } & \text { I-past-catch } \\ \text { i-mbómbo } & \text { pá-ndawíndaawi } & & \\ \text { cl9-work in-morning } & & \\ \text { 'The day my child was born I worked in the morning' } & \end{array}$

Head of $R C$ is other adjunct

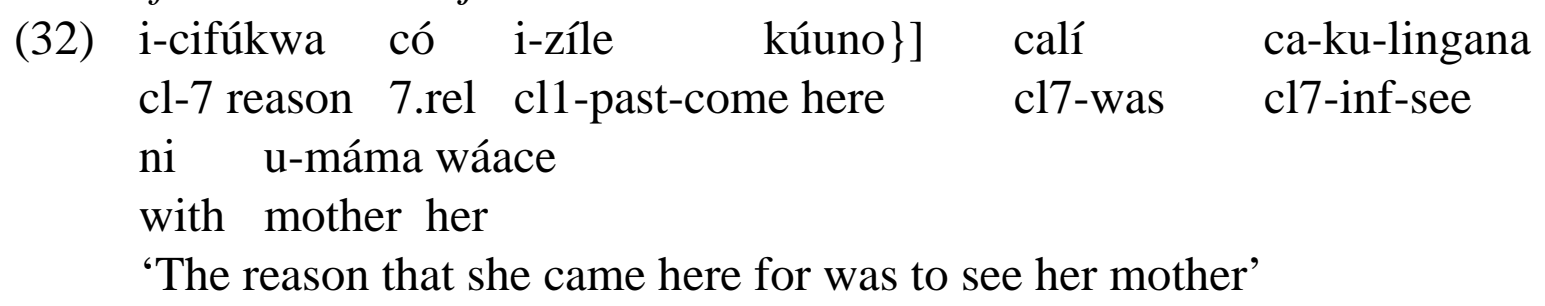

The prosodic phrasing pattern shown by locative, temporal and other adjuncts in the data above also occurs even when these expressions are in embedded constructions where they serve as heads of relative verbs. In all these cases, the main clause and the relative morpheme phrase with the relative clauses. As seen in the examples below, there are no long penultimate vowels and contour tones in front of the relative clauses. This shows that the entire construction serves as one phonological phrase.

Locative as head of embedded relative clause

(33)
n-tha-ménye kó a-kw-íkhaala\}]
I-neg-know loc.rel
cl1-prog-live
'I don't know where she lives'

Temporal expression as head of embed relative clause 
(34)

n-tha-ménye pó wa-li-fíika\}]

I-neg-know temp.rel cl2-fut-arrive

'I don't know when they will arrive'

Adverbial adjunct as head of embedded $R C$

(35)
n-tha-ménye mó wa-ka-fik-ila kúuno\}]
I-neg-know adv.rel cl2-past-arrive-appl here
'I don't know how they got here'

As would be expected, however, when locatives, temporal or other expressions occur as heads of non-restrictive clauses, they phrase separately from the RCs as seen in (36) and (37) below where the NPs [Zóomba] and [sabáata], which are the heads of the relative clauses, have long penultimate syllables (with falling tones), a sign that they are phrase final.

Locatives in non-restrictive relative clause

(36) ku Zóomba] kó n-ki-kháala\}] ku-ku-wanga í-mvulá nkháani loc-Zomba loc.reI I-hab-past-live loc-hab-come cl9-rain much

'In Zomba, where I used to live, it rains a lot'

Temporal expression in non-restrictive relative clause

(37) pa-sabáata] pó n-ka-fika kúuno\}] i-mvula yi-ka-wa

loc-Sunday loc.rel I-past-arrive here cl9-rain cl9-past-fall

i-siku lyoonse

cl5-day cl5-all

'On Sunday, when I arrived here, it rained all day'

Another instance when locative and temporal expressions phrase separately from their relative verbs is, as would be predicted, when they occur in cleft constructions as noted in the example below where the NP for "Sunday", [sabáata] has a long penultimate vowel with a falling tone, showing its phrase finality.

po sabáata] pó u-Mary í-nti-íze kúuno\}]

cop-Sunday loc.rel cl1-Mary cl1-fut-come here

'It's on Sunday that Mary will come here' 


\section{Al Mtenje}

\section{Coordinated relatives}

When restrictive non-clefted relative clauses are coordinated, the expected phonological phrasing occurs. First, the head of each RC (regardless of whether it is the subject, object, locative, temporal or other expression) phrases with the relative verb and therefore no long vowels occur within the relative clause. Thus, each half of the conjoined relative clauses is wrapped as a phonological phrase. Second, we find the usual phonological phrase boundary at the end of each RC since their edges always mark the end of phonological phrases. This is illustrated in the examples below.

a-wána wa-sukúlu wó wa-welénga i-búuku\}] sóna wa-malízya
cl2-child cl2-school 2.rel cl2-read cl5-book and cl2-finish
$\begin{array}{llll}\text { i-mbómbo zyaawo\}] } & \text { wa-nga-wéla ku-nyúumba } \\ \text { cl9-work their } & \text { cl2-can-return loc-home }\end{array}$

'The students who have read the book and have finished their work, can return home'

In this example, the head of the RC, [a wána wa sukúlu] (students) phrases with the verb in the first half of the coordinated relatives as seen in the fact that it does not have a long penultimate vowel and a falling tone on the word [sukúlu]. The only phrase break is at the end of the $\mathrm{RC}$ as noted in the falling long penultimate vowel in the word [ibúuku]. The second half of the coordinated RCs ("who have finished their work"), behaves in a similar manner in that we find only one position where there is a long vowel, namely, in the word [zyaawo]. Again, this is evidence that there is only one prosodic phrase boundary which, predictably, coincides with the right edge of this $\mathrm{RC}$.

The same observations apply in the example in (40) where the head of the first relative clause [awalwale] phrases together with the relative verb and the only phrase break is at the end of the RC where we find a long penultimate vowel in the word [yaawo]. The second relative clause ("who have paid their bills") also has only one phonological phrase edge at the end of the clause as seen in the long vowel in the word [zyaawo]. 
a-walwale wó wa-pokela i-milémbo yaawo\}] pámo wa-lipila cl2-patients 2.rel cl2-receive cl9-medicine their or cl2-paid i-ndaláma zyaawo\}] wize i-sabáta yó-yi-kwíiza\}] cl9-money their should come cl9-week 9.rel-cl9-prog-come 'The patients who have received their medication or who have paid their bills, should come back next week'

\section{Extraposed relatives}

When a relative clause is extraposed, the RC and the main clause are each wrapped as separate prosodic phrases. The example below illustrates this.

(41) The man came into the room, whom we all knew (extraposed from the sentence "We all knew the man who came into the room").

u-múnthu a-ki-za mu-ci-píinda] yó towónse tu-ka-mu-máanya\}]

cl1-person cl1-past-come in room 1.rel all we-past-obj1-know

In (41) above, the main clause [u-múnthu a-ki-za mu-ci-píinda] has a long and falling penultimate vowel on its final word [mu-ci-píinda] showing a phonological phrase break which separates that clause from the RC. The exraposed relative clause, [yó towónse tu-ka-mu-máanya] also has only one phonological phrase boundary in the expected position, namely on its right edge. All this shows that the two clauses are prosodically separated by a phrase break.

\section{$9 \quad$ Long distance relativization}

In long distance relativization, the whole relative clause is wrapped as one phrase, regardless of its length. This is not entirely surprising since Ciwandya seems to show a tendency of wrapping sequences of XPs into one phrase instead of each XP serving as a separate phonological phrase as is the case in other Bantu languages (cf. Manus 2010 for Símákonde, for example). The phonological phrasing in long distance relativization is shown in the examples in (42) and (43) below. 


\section{Al Mtenje}

(42)

u-mú-luméndo yó mu-ku-swigha u-ku-ti kali u-nálúmé wane
$\begin{array}{llll}\text { cl1-boy } & \text { 1.rel cl1-prog-wonder that } & \text { if cl1-uncle my } \\ \text { nalóli a-ka-mu-manyisyáa-po\}] } & \text { a-wina } & \text { i-mpháaso } \\ \text { really cl1-past-1.obj-teach-really } & \text { cl1-won } & \text { cl9-prize }\end{array}$

'The boy who you wonder whether my uncle really taught (him) won a prize’

u-múnthu yó n-ku-mw-i-nong'on-ela u-kuti u-ka-nena náaye \}] cl1-person 1.rel I-prog-1.obj-think.applic that you-past-talk with.him a-ká-m-pusiika cl1-past-1.obj-fool

'The person to whom I think you talked lied to me.' [Lit., 'The person who I am thinking of that you talked with him/her fooled me']

In (42) there is only one long penultimate syllable in the relative clause which also bears a falling tone. This is found in the form [a-ka-mu-manyisáapo]. The long penultimate syllable coincides with the right edge of the $\mathrm{RC}$, where we find the only phonological phrase break in the entire construction. Likewise, in (43) the only long penultimate syllable is found at the right edge of the RC in the form [náa-ye], showing the only prosodic phrase boundary in the whole construction. Thus, we can conclude that in Ciwandya, the phonological phrasing of relative clauses is not influenced in any way by the distance between their heads and the rest of the clause.

\section{Prosodic phrasing and syntax}

There has been considerable attention in recent work on the syntax-phonology interface of the type discussed in the preceding sections particularly, the relationship between syntactic constituency and the phonological phrasing of relative clauses (cf. Truckenbrodt 1995, 1999, Kanerva 1990, Cheng \& Downing 2007, Downing \& Mtenje, 2010, 2011, Mtenje 2011, Kanerva 1990, Bresnan \& Kanerva 1989, Selkirk 2000, Simango 2006 among others). What has been noted in this paper is that in Ciwandya, XPs which are heads of restrictive relative clauses do not form separate phonological phrases but phrase with the rest of the relative construction, whose right edge always coincides with a phonological phrase break. This shows that there is no XP edge following the head of the RC. A 
similar situation has been noted and argued for in languages like Chichewa (cf. Downing \& Mtenje 2010, 2011).

In this paper, we assume the analysis proposed by Cheng \& Downing 2007, Cheng \& Downing 2010, to appear, and Downing \& Mtenje 2010, 2011 initially for Zulu and Chichewa but which has sufficient generality to apply to other Bantu languages with similar phonological phrasing patterns as well. Essentially, the analysis adopts a phase-based syntactic approach for such languages and proposes that the head of a restrictive relative is within the $\mathrm{CP}$ which is, itself, a complement of the D head. This syntactic structure, and the constraints given below in (44) and (45), account for why the right edge of a relative clause always coincides with a phonological phrase edge.

ALIGN R [PHASE, INT PH]

Align the right edge of every phase $(\mathrm{vP} / \mathrm{CP})$ with the right edge of an intonation phrase (IntPh).

(46) ALIGN R [INT PH, PHASE]

Align the right edge of every intonation phrase (intPh) with the right edge of a phase (vP/CP).

(Cheng \& Downing 2010: 38)

Following these constraints, which require the right edges of intonation phrases to coincide with the right edges of $\mathrm{vP} / \mathrm{CP}$ phases, we predict that the right edge of a restrictive relative clause in Ciwandya, whose head is within the CP phase, will have a phonological break since the right edge of that phase coincides with that of an intonation phrase.

The same syntactic structure given above accounts for cases where heads of relatives in cleft constructions phrase separately. The analysis argues that in a cleft structure, the pivot of the cleft is in a copular sentence to which is adjoined the headless DP which contains the relative clause. Since the constraint in (45) predicts that the right edge of a CP phase always conditions a phonological phrase break, the structure explains why clefts in relatives are phrased separately from their relative verbs in languages like Ciwandya.

\section{Conclusion}

In this paper, we have observed the following general patterns regarding the phonological phrasing of relative clauses when they occur in different syntactic 


\section{Al Mtenje}

constructions in Ciwandya. The head of a relative clause is not set off by a phonological phrase break except when it is in a non-restrictive RC, in clefts or when it occurs in extraposed expressions. This is regardless of whether the head is a subject, direct object or indirect object of the RC or a locative, temporal, instrumental or other adjunct. We noted that by showing this phrasing pattern, Ciwandya differs from some other Bantu languages where heads of RCs do not phrase together with relative verbs which follow them. The right edge of relative clauses is always marked by a phonological phrase boundary. Headless relatives behave like ordinary relative clauses in that only the right edge of the RC is wrapped as a prosodic boundary. Extraposed relatives behave like clefts in that their main clauses are phrased separately from the RCs. In coordinated relatives, each half is wrapped as a phonological phrase. Even in long distance relativization, heads of RCs still phrase together with their relative verbs.

\section{References}

Bresnan, Joan \& Jonni Kanerva (1989). Locative inversion in Chichewa: a case study of factorization in grammar. Linguistic Inquiry 20, 1-50.

Cheng, Lisa \& Laura Downing (2007). The Phonology and Syntax of Relative Clauses in Zulu. Bantu in Bloomsbury: Special Issue on Bantu Linguistics. SOAS WPL 15, 51-63.

Cheng, Lisa \& Laura Downing (2010). Locative relatives in Durban Zulu. ZAS Papers in Linguistics 53, 33-52.

Cheng, Lisa \& Laura Downing (to appear). Clefts in Durban Zulu. In: Haida Andreas, Hartman Katherina \& Veenstra Tonjes (eds.). The structure of clefts. Amsterdam: John Benjamins.

Cheng, Lisa \& Nancy Kula (2006). Syntactic and phonological phrasing in Bemba relatives. ZAS papers in Linguistics 43, 31-54.

Downing, Laura \& Al Mtenje (2010). The prosody of relative clauses in Chewa. ZAS papers in Linguistics. No. 53, 53-68.

Downing, Laura \& Al Mtenje (2011). Prosodic phrasing of Chichewa relative clauses. Journal of African Languages and Linguistics.

Henderson, Brent (2006). The syntax and typology of Bantu relative clauses. Ph.D. Dissertation. University of Illinois at Urbana-Champaign.

Kanerva, Jonni M (1990). Focus and Phrasing in Chichewa Phonology. New York: Garland.

Kisseberth, Charles (2010). Phrasing and relative clauses in Chimwiini. ZAS papers in Linguistics 53, 109-144. 


\section{On Relative Clauses and Prosodic Phrasing in Ciwandya}

Manus, Sophie (2010). The prosody of Símákonde relative clauses. ZAS papers in Linguistics 53, 159-186.

Mchombo, Sam (2004). The Syntax of Chichewa. Cambridge University Press.

Miti, Lazarus, (2002). Aspects of Cinsenga Tonology. Centre for Advanced Studies of African Society. Cape Town, South Africa.

Morimoto, Yukiko (2007). Some morpho-syntactic aspects of Chichewa relative clauses. Paper presented at CALL 37, Leiden University, 27-29 August 2007.

Morimoto, Yukiko \& Laura Downing (2007). A new look at verb-raising in Bantu object relatives. Paper presented at LFG-07, Stanford University 26-28 July 2007.

Mtenje, Al (2011). On relative clauses and prosodic phrasing in Cisena. Paper presented at the $11^{\text {th }}$ Linguistics Association for SADC Universities (LASU) conference, University of Zambia, Lusaka, 9th-11th May 2011.

Selkirk, Elisabeth (1986). On derived domains in sentence phonology. Phonology Yearbook 3, 371-405.

Selkirk, Elisabeth (2000). The interaction of constraints on prosodic phrasing. In: M. Horne (ed.). Prosody: Theory and Experiment. Kluwer Academic Publishers, 231-261.

Simango, Silvester Ron (2006). Verb agreement and the syntax of ciNsenga relative clauses. Southern African Linguistics and Applied Language Studies 24, 277-190.

Truckenbrodt, Hubert (1995). Phonological Phrases: their relation to syntax, focus and prominence. PhD dissertation, MIT.

Truckenbrodt, Hubert (1999). On the relation between syntactic phrases and phonological phrases. Linguistic Inquiry 30, 219-255.

Zeller, Jochen (2006). On the relation between noun prefixes and grammaticalization in Nguni relative clauses. Studia Linguistica. 60 (2), 220-249. 